\title{
The Influence of HRM Practices on Employee Behavioural Intentions: Do Generational Differences Matter?
}

Shariff Harun, Siti Asiah Md Shahid, Abdul Kadir Othman, Mohd Khirzan Badzli A Rahman, and Darma Tasiyah Gumbri

To Link this Article: http://dx.doi.org/10.6007/IJARBSS/v11-i4/9668

DOI:10.6007/IJARBSS/v11-i4/9668

Received: 15 February 2021, Revised: 18 March 2021, Accepted: 05 April 2021

Published Online: 16 April 2021

In-Text Citation: (Harun et al., 2021)

To Cite this Article: Harun, S., Shahid, S. A. M., Othman, A. K., Rahman, M. K. B. A., \& Gumbri, D. T. (2021). The Influence of HRM Practices on Employee Behavioural Intentions: Do Generational Differences Matter? International Journal of Academic Research in Business and Social Sciences, 11(4), 284-294.

Copyright: (c) 2021 The Author(s)

Published by Human Resource Management Academic Research Society (www.hrmars.com)

This article is published under the Creative Commons Attribution (CC BY 4.0) license. Anyone may reproduce, distribute, translate and create derivative works of this article (for both commercial and non-commercial purposes), subject to full attribution to the original publication and authors. The full terms of this license may be seen

at: http://creativecommons.org/licences/by/4.0/legalcode

\section{Vol. 11, No. 4, 2021, Pg. 284 - 294}

Full Terms \& Conditions of access and use can be found at http://hrmars.com/index.php/pages/detail/publication-ethics 


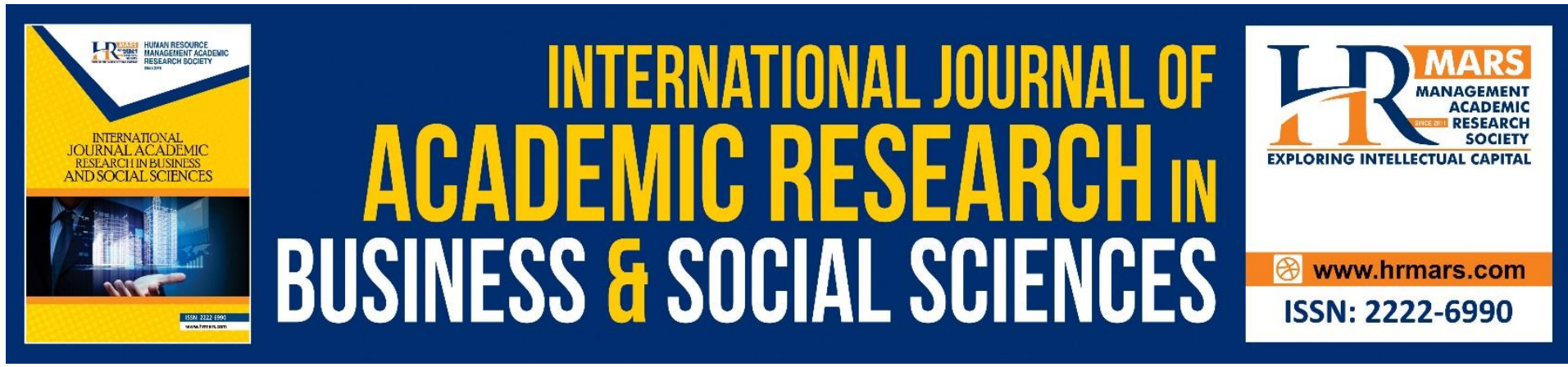

\title{
The Influence of HRM Practices on Employee Behavioural Intentions: Do Generational Differences Matter?
}

\author{
Shariff Harun ${ }^{1}$, Siti Asiah Md Shahid², Abdul Kadir Othman ${ }^{3}$, \\ Mohd Khirzan Badzli A Rahman ${ }^{4}$, and Darma Tasiyah Gumbri ${ }^{5}$ \\ ${ }^{1}$ Faculty of Business and Management, Universiti Teknologi MARA, UiTM Puncak Alam \\ Campus, 42300 Puncak Alam, Selangor, Malaysia, ${ }^{2}$ Institute of Business Excellence, Faculty \\ of Business and Management, Universiti Teknologi MARA, 40450 Shah Alam, Selangor, \\ Malaysia, ${ }^{3}$ Faculty of Business and Management, Universiti Teknologi MARA, 40450 Shah \\ Alam, Selangor, Malaysia. ${ }^{4}$ Institute of Business Excellence, Faculty of Business and \\ Management, Universiti Teknologi MARA, 40450 Shah Alam, Selangor, Malaysia, ${ }^{5}$ Sekolah \\ Menengah Jenis Kebangsaan San Min, 36000 Teluk Intan, Perak, Malaysia. \\ Email: shariffharun@uitm.edu.my, sitia348@uitm.edu.my, abdkadir@uitm.edu.my, \\ khirzan@uitm.edu.my, tasya0409@gmail.com
}

\begin{abstract}
Generational diversity plays an important role in many aspects of organizational functions including Human Resource Management (HRM). However, studies are limited to proving this role. Management understanding of the effects of generational diversity and HRM practices is very important because it can foster a positive work environment that can encourage a competent employee to remain with the organization. To achieve the objective, this study utilises descriptive research design and the data was gathered through survey questionnaires comprised of 272 non-academic staff from Malaysian Private Higher Learning Institutions (PHLIs). Results revealed that the participants moderately agree with their intention to stay in the organisation. However, generational diversity was found as not having any significant effect on the relationships between the HRM practices dimensions performance appraisal, training, and selection, and intention to stay. Efforts to increase the non-academic staff intention to stay should focus on enhancing the organisation's training and performance appraisal system.
\end{abstract}

Keywords: Generational Diversity, HRM Practices, Non-Academic Staff, Private Higher Learning Institutions

\section{Introduction}

The changes in the present economic situation and the stiff rivalry among competitors have changed the way employees react at their workplace. This adds further to the issue of diverse age groups of employees that have different expectations. According to Aminuddin (2014), generational differences between individuals in today's workplace do exist, this is 
because each generation thinks, acts and lives in very different ways and the key factors influencing them are based on the key historical and social life events that happened in their life. Undeniably, understanding the discrepancy between the generational work values and organisations' norms is a very crucial task, failure to do so might decrease the individual's job satisfaction and might trigger their negative behaviours such as absenteeism and tardiness, that can lead to turnover behaviour (Gursoy, Chi, \& Karadag, 2013). To create a harmonious working environment, age management approach, whereby, treatments of employees are based on employee's age groups, might be an effective mechanism that organisation should practice (Nitya \& Anand, 2016).

As such, organisations need to modify their Human Resource Management (HRM) practices to suit the expectations of the various age groups to attract and retain them. This is because previous scholars reported that different groups of employees were found to not respond to HRM practices in the same way (Meijerink, Bondarouk, \& Lepak, 2016). Therefore, the generational differences highlighted by previous researchers may no longer be accurate and reliable as they may only represent the feelings of the older generations (Stone \& Deadrick, 2015). Thus, the HRM practices that satisfy the ageing workforce might not be effective if applied to the younger generation. Hence, more studies are needed to understand the values of HRM practices to different age groups of workers, especially within the context of the Malaysian service sector (Ahmad \& Ibrahim, 2015). Subsequently, in the context of this study and consistent with the findings by present studies focuses on Malaysian education workforce, the HRM practices proposed for this study are recruitment and selection, training and development, performance appraisal, and compensation and benefits (Harun, Shahid, \& Othman, 2016, 2017; Shahid et al., 2018).

Pertaining to the generational diversity, the Department of Statistics Malaysia (2019), reported that as of July 2019, the total Malaysian workforce population consisted of approximately 15.18 million people ranging from the age of 15 to 64 years old. Specifically, according to Aminuddin (2014), the Malaysian workforce is composed of several generations, the Baby Boomers (those born from 1946 to 1964), Generation X (those born from 1965 to 1979), and Generation Y or also known as the Millennials (those born from 1980 to 2000). Most of the employees from the Silent Generations (those who were born before 1946) are already retired and the new group of employees that is the Generation Z (those born after the year 2000) would only be joining the industry after the year 2020 (Hendricks \& Cope, 2013). Hence, due to the scarcity of research on generational diversities in the Malaysian workforce, this study aims to investigate the effects of generational diversities in the Malaysian context and cross-validate the generational differences as reported by other studies done on other parts of the world. Therefore, this study intended to find answers to the following questions:

1. To what extend do HRM practices influence intention to stay?

2. To what extend does generational diversity moderate the relationship between HRM practices and intention to stay?

\section{Literature Review}

Parry and Urwin (2011) reported that the Generational Theory was first introduced by Mannheim (1952) and according to this theory:

...belonging to the same generations or age group endows the individuals sharing in

(it) with a common location in the social and historical process, thereby limiting them to a 
specific range of potential experiences, predisposing them for a certain characteristic mode of thought and experience, and a characteristic type of historically relevant action (p. 291).

Hence, based on the above definition, Howe and Strauss (1991) stressed that the above aspects stand as the basic principal value that contributes towards common generational characteristics that make each generation share similar traits, thinking, values and beliefs. Concerning this, Nitya and Anand (2016) reported that although a generation can be defined by both its years of birth and the specific set of shared social and economic conditions that have a profound and lasting influence on the groups' development, ultimately, the separation of generations is commonly done based on age.

Gursoy et al. (2013) in their study on generational differences in work values and attitudes among frontline and service contract employees concluded that there are sevenfactor dimensions of differences in work values among the Baby Boomers, Generation X, and Generation Y. The first factor is "work centrality". This dimension emphasises on the importance of the job towards the employee's life. Employees with this value are job oriented, thus their life is likely to rotate around their job. The second factor is "noncompliance". Employees with this type of behaviour like to challenge conventional norms and their superior. They do not like bureaucracy, and they tend to challenge their superior, organisational rules and colleagues if work conflict arises. The third factor is "technology challenge". Here, the employees' work-life is directly influenced by the changes in technology. They will be frustrated if they are not provided with sufficient training to enable them to adapt to the changes, or if they think that, the technology provided to them is outdated.

"Work-life balance" has been reported as the fourth factor. This factor focuses on the need to separate work matters with personal life-related matters. Employees with this value focus more on life outside of work because it is more important matters compared with work itself. To them, work is just the intermediary for them to earn their salary for the sake of survival. The next factor is "leadership", whereby, employees need a strong and competent leader to direct, support, and monitor their work performance. This category of employees tends to work best if provided with a clear work direction on how their work can assist the organisation to achieve organisational goals and they might leave the organisation if the leader's performance fails to fit their work standard perceptions. The sixth factor is "power". It is related to the power struggle among employees. Employees with this value like to be in control and will always strive for power. Hence, although provided with clear job roles and lines of authority, these employees will find ways to oversee something or someone. The last factor is "recognition", and this factor is directly related to the young generation. This group of employees perceive that they did not get the right respect and consideration because they are young and this unfair treatment occurs in various forms such as their opinions or comments are not being listened to, being assigned with a meaningless task, or always left out from the decision-making process. Therefore, it is up to the organisation to view these differences as opportunities or obstacles to enhance their workforce environments.

Gursoy et al. (2013) further suggested that the generational differences may bring noticeable effects on the attitudes of employees and this may influence their interactions with their colleagues, superiors, and customers. If these differences are not well managed, dissatisfactions and tensions will exist among the employees in the workplace. On the other hand, if the organisation can cope and handle the differences well, it will create positive working environments, which can stimulate leadership, motivation, communication, and generational synergy. This will decrease turnover intention, preventing employees from leaving and increasing organisational well-being. They further added that management needs 
to realise that the previous strategies practised by the organisation to manage and motivate the Baby Boomers and Generation X employees, might no longer suit the Generation $Y$ employees because of the differences in their characteristics.

These findings are further supported by Pinto, da Silva Ramos, and Nunes (2014) in their study on the value of HRM practices to the different age groups of workers. The study found that due to those differences, in future, it would be tough for the HRM managers to design effective HRM practices that can increase the employability and intention to stay of their workforce. Therefore, organisations need to put extra efforts in retaining their workforce, especially those with special talents, extensive knowledge, and relevant experiences. The researchers also reported that the results of their study showed that all generation cohorts give their highest value to HRM practices such as training, rewards, and recognition and participation. Above all, performance evaluation topped the list. Therefore, the ability of the organisation to synergise the differences between the organisations' effective HRM practices and the HRM practices that the employees deem important will have positive consequences in encouraging the employees to remain with the organisation. This will prevent employers from losing their skilled employees and organisational advantages.

\section{Methodology}

This study utilises a descriptive research design and specifically, the cross-sectional approach. The mean and standard deviation scores were used to examine the perception levels of agreement of the four dimensions of HRM Practices. The correlation coefficient analysis was then used to measure the association between HRM practices and intention to stay. Finally, to examine the moderating effects of generational diversity on the relationship between HRM practices and intention to stay, the three-step hierarchical regression analyses were performed.

To collect the data for each study variable, a structured self-administered questionnaire based on established instruments were used. HRM practices were measured using 20 items adopted from several sources. Delery and Doty (1996) instruments were used to measure training and development ( 8 items) and performance appraisal (4 items). Khatri (2000) instruments were used to measure compensation and benefits (4 items), and recruitment and selection ( 4 items). While, a seven items instrument developed by Mowday, Koberg, and McArthur (1984) and Walsh, Ashford, and Hill (1985) were used to measure the employee intention to stay. A 5-point Likert Scale, ranging from $1=$ strongly disagree to $5=$ strongly agree was applied as the measuring scale. Lastly, to analyse generational diversity effects, this study uses the demographic data that requires the respondents to choose the best range of years that fits the year they were born.

In determining the sample for this study, the purposive non-probability sampling technique was utilised because it is impossible to obtain a comprehensive list of the population. Albeit 279 responses received, only 272 responses were accepted, coded, and analysed because the remaining responses did not fit the participants' criteria. The respondents for this study were non-academic staff from Malaysian Private Higher Learning Institutions (PHLIs) within the Management and Professional grade (whose jobs are equivalent to grade 41 to 54 of the Malaysian public service). To eliminate any bias and possible differences in terms of needs and expectations, only full-time non-academic staff with a minimum of one-year service appointment were chosen as respondents for this study. 


\section{Analysis}

In determining the validity of HRM practices scale, the exploratory factor analysis was conducted. The principal components factor analysis with Kaiser Normalization varimax rotation method was used to determine the appropriateness and dimensionality of the factors. The initial results of the analysis did not produce a clean and meaningful structure. The results revealed that 10 items had either high cross-loadings ( 0.35 and above) or low factor loadings ( 0.50 or below). The items were eliminated from further analyses and the remaining 10 items were factor analysed again.

The results of factor analysis on HRM practices indicated the existence of three significant factors. The results of a scree test also provided support for a three-factor solution. The first factor comprised of five items relating to the performance appraisal. It was mainly concerned with the participants' perceptions with the processes involved in the performance evaluation that include the reliability and objectivity of the evaluation process, formal feedback systems, the criteria and technique utilised in the evaluation process, and aspects of assessment. Therefore, the name Performance Appraisal was retained and categorised as Factor 1.

Factor 2, which was represented by three items, was named Training because it was more concerned with the participants' perceptions about the training programmes. The final factor, Factor 3 represented by two items, which reflected the participants' perceptions of the selection process. Hence, this factor was named as Selection.

On the other hand, the factor analysis results obtained from the seven items of intention to stay resulted in a single factor. The results of a scree plot test also supported the one-factor solution. This is consistent with the original conceptualisation of intention to stay as unidimensional. Since only one component was extracted, the solution could not be rotated. Therefore, the seven items measuring intention to stay were retained as per the original construct because the items were interrelated, and they share common factors.

The outcome from the factor analyses resulted in some of the earlier identified variables being deleted, re-categorised and renamed. Therefore, below research framework was developed as guidelines for this study.

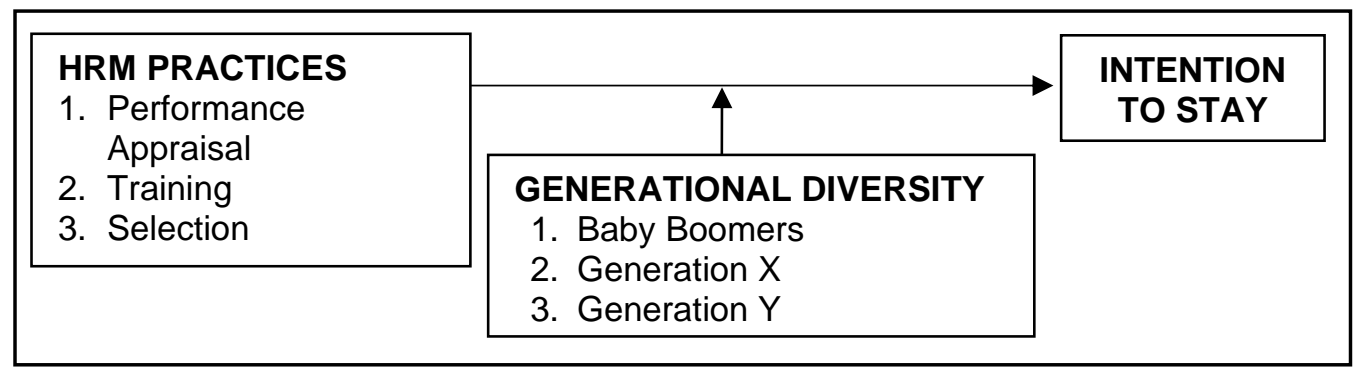

Figure 1: Research Framework

Subsequently, based on the findings from the factor analyses, below hypotheses were formulated:

H1 Performance appraisal has a significant influence on the intention of non-academic staff to stay at PHLIs

H2 Training has a significant influence on the intention of non-academic staff to stay at PHLIS

H3 Selection has a significant influence on the intention of non-academic staff to stay at PHLIS 
H4 Baby Boomers moderates the relationship between performance appraisal and intention of non-academic staff to stay at PHLIs

H5 Baby Boomers moderates the relationship between training and intention of nonacademic staff to stay at PHLIs

H6 Baby Boomers moderates the relationship between selection and intention of nonacademic staff to stay at PHLIs

H7 Generation $X$ moderates the relationship between performance appraisal and intention of non-academic staff to stay at PHLIs

H8 Generation $X$ moderates the relationship between training and intention of nonacademic staff to stay at PHLIs

H9 Generation $X$ moderates the relationship between selection and intention of nonacademic staff to stay at PHLIs

H10 Generation $Y$ moderates the relationship between performance appraisal and intention of non-academic staff to stay at PHLIs

H11 Generation $Y$ moderates the relationship between training and intention of nonacademic staff to stay at PHLIs

H12 Generation $Y$ moderates the relationship between selection and intention of nonacademic staff to stay at PHLIs

\section{Results}

Table 1 shows the reliability of independent and dependent variables. The Cronbach's Alpha for the variables fall within the range of 0.74 (good reliability) to 0.92 (very good reliability) indicating that the measures used in this study are highly reliable and can be used for further analyses. In this study, the measure by Zikmund, Babin, Carr, and Griffin (2013) was adopted, "very good reliability" is when $0.80<\alpha<0.95$; "good reliability" is when $0.70<\alpha<0.80$; "fair reliability" is when $0.60<\alpha<0.70$; and "poor reliability" is when $\alpha<0.60$. Findings in the table below also indicated that the non-academic staff in this study had a moderate perception regarding the existence of a formal performance appraisal process, training programme, and selection mechanism at their respective universities. The "Intention to stay" felt by the nonacademic staff was also reported to be at a moderate level. This study used the following criteria: mean scores of 2.99 or less are considered "low", mean scores between 3.00 and 4.99 are categorised as "moderate", and mean scores of 5.00 and above are categorised as "high".

Table 1: Reliability of Independent and Dependent Variables

\begin{tabular}{lcccc}
\hline Variables & $\begin{array}{c}\text { Number of } \\
\text { Items }\end{array}$ & $\begin{array}{c}\text { Cronbach's } \\
\text { Alpha }\end{array}$ & Mean & itandard Deviations \\
\hline Performance & 5 & 0.74 & 3.54 & 0.62 \\
Appraisal & 3 & 0.83 & 3.38 & 0.86 \\
Training & 2 & 0.77 & 3.35 & 0.84 \\
Selection & 7 & 0.92 & 3.22 & 0.85 \\
Intention to stay & 7 & & \\
\hline
\end{tabular}

Table 2 shows the regression analysis results conducted to analyse the participants' perceptions about their organisation's HRM Practices on their behavioural intention (intention to stay) as per hypotheses statement $\mathrm{H} 1, \mathrm{H} 2$ and $\mathrm{H} 3$ above. The results showed significance effect, $F(3,268)=25.95, p<0.000$. This indicates that the inclusion of independent variables improved the model significantly. The individual interactions results 
indicated that Training $(\theta=0.30, p<0.001)$ had the most impact on intention to stay, followed by Performance Appraisal $(B=0.21, p<0.001)$. Selection was not significant in predicting intention to stay.

Table 2: The Influence of HRM Practices on Intention to Stay

\begin{tabular}{lc}
\hline Predictors & Std. $\boldsymbol{B}$ \\
\hline Performance Appraisal & $0.21^{* *}$ \\
Training & $0.30^{* *}$ \\
Selection & 0.06 \\
\hline$R^{2}$ & 0.23 \\
$F$ & 25.95 \\
Significance $F$ & $0.00^{* *}$ \\
\hline Note: ${ }^{*} p<0.01 ; * p<0.001$ &
\end{tabular}

To examine the effects of generational diversity as the moderating variable, the threestep hierarchical regression analyses were performed. The results in Table 3 indicated that all three generational diversity cohorts (Baby Boomers, Generation X and Generation $Y$ ) did not significantly moderate the relationships between HRM practices and intention to stay. The results indicated that the $R^{2}$ change for all three generational cohorts were 0.01 and 0.02 , respectively. These values indicating that the inclusion of interaction terms between HRM practices and baby boomers only produced significant increment of $0.1 \%(F(7,264)=12.36$, $p=0.00)$ to intention to stay. While the inclusion of interaction terms between HRM practices and Generation X only produced significant increment of $0.2 \%(F(7,264)=13.76, p=0.00)$ to intention to stay. Finally, the inclusion of interaction terms between HRM practices and Generation $Y$ only produced significant increment of $0.2 \%(F(7,264)=7.70, p=0.00)$ to intention to stay. Based on these results, it can be concluded that the hypotheses on the moderating effects of all generational diversity cohorts (Baby Boomers, Generation X, Generation $\mathrm{Y}$ ) between HRM practices variables (performance appraisal, training and selection) and intention of non-academic staff to stay at PHLIs were not supported.

Table 3: Influence of Generational Diversity on the Relationship between HRM Practices and Intention to Stay

\begin{tabular}{lccc}
\hline Items & $\begin{array}{c}\text { Baby Boomers } \\
\text { Std. } \mathbf{~}\end{array}$ & $\begin{array}{c}\text { Generation X } \\
\text { Std. } \boldsymbol{~}\end{array}$ & $\begin{array}{c}\text { Generation } \mathbf{Y} \\
\text { Std. } \mathbf{~}\end{array}$ \\
\hline$R^{2}$ & 0.25 & 0.27 & 0.28 \\
Adjusted $R^{2}$ & 0.23 & 0.25 & 0.26 \\
$R^{2}$ Change & 0.01 & 0.02 & 0.02 \\
$F$ Change & 1.26 & 2.36 & 1.85 \\
Significance $F$ Change & 0.29 & 0.07 & 0.14 \\
Durbin-Watson & 1.70 & 1.72 & 1.72 \\
\hline
\end{tabular}

Note: ${ }^{*} p<0.05 ;{ }^{* *} p<0.01 ;{ }^{* *} p<0.001$

\section{Conclusion}

This study intended to analyse the effects of non-academic staff's perceptions regarding the HRM practices of their PHLIs in influencing their behavioural intention (intention to stay). Therefore, hypotheses tests were performed on the collected data to answer the questions posited in Hypotheses 1, 2 and 3. The results revealed that only two 
dimensions of HRM practices, namely performance appraisal and training significantly and positively influenced the non-academic staff's behavioural intention (intention to stay). Training was the strongest predictor of the intention to stay of the non-academic staff, followed by Performance Appraisal. While Selection was not a significant predictor of intention to stay.

With the findings, four empirical results can be discussed here. The first result is that training indeed has a direct effect on the intention to stay of the non-academic staff. The findings from this study indicated that when non-academic staff perceive that they are provided with relevant training related to their future career development, conducted formally to prepare them for the job and coupled with a very extensive training programme, they tend to experience a higher sense of belonging. This will create loyalty and motivate them to stay longer with their respective PHLIs.

The second empirical result which can be discussed here is that performance appraisal has a direct effect on the intention to stay of non-academic staff. Results from the study showed that when the non-academic staff perceive that the performance appraisal process being practised by the organisation is reliable and objective, supported by transparent promotion process, and the staff are aware on the availability of positions for promotion, it will positively influence the behavioural intention (intention to stay) of the non-academic staff. This is especially when the head of the department is supportive and aware of the career aspirations of their staff, and they support it through a clear and objective performance process practices. Ultimately, this will increase their job satisfaction, will provide them with a sense of purpose, will make them feel valued and thus they will increase their loyalty.

The third empirical result which can be discussed here is that selection did not have any significant influence on the intention to stay of the non-academic staff. Although the PHLIs may have an effective selection process, this factor failed to bring a positive impact on the intention to stay of the non-academic staff. One possible explanation might be that the non-academic staff did not see the importance of selection in their current employment since they are already in the system. This factor is more relevant to the hiring process of a new breed of employees into the PHLIs. Furthermore, selection which in most cases is conducted seasonally by specific department or personnel, may neither bring any direct impact nor provide any immediate result to their work assignment. Therefore, this might explain why the factor selection does not influence the intention to stay of non-academic staff.

Finally, the fourth empirical result is on the moderating effects of generational diversity. The final hypothesis tests revealed that all nine hypotheses $-\mathrm{H} 4, \mathrm{H} 5, \mathrm{H} 6, \mathrm{H7}, \mathrm{H}$, $H 9, H 10, H 11$, and $H 12$ were not significant. Results indicated that generational diversity did not significantly moderate the relationships between all three HRM practices dimensions performance appraisal, training, and selection and intention to stay. Hence, the conclusion is that the differences in age groups or cohort of non-academic staff, which signify the differences between Baby Boomers, Generation $X$ and Generation $Y$ groups that coexisted in the organisation, had no significant effects on the HRM practices dimensions implemented by their organisation and did not influence their intention to stay. It is also important to note that the results of this study also indicated that factors that encourage the intention to stay of the non-academic staff are not linked to the attitude of the generational differences in the workforce.

This study offers important contributions to the existing works of literature because as at to date, only a few published studies have done a comparison of the effects of HRM practices on non-academic staff behavioural intention (intention to stay). This study is also 
original in that it proposes a longitudinal study of the relationships between HRM practices and employees' retention, specifically in the education sector. In this sector, soft skills are key skills to be safeguarded because it is an essential skill needed in the service industry. Ultimately, as shown in this study, there are significant relationships between the factors such as training and performance appraisal in influencing the intention to stay of non-academic staff at Malaysian PHLIs.

Therefore, to increase the employees' intention to stay, organisations should focus on training (training for future career development, formal training to prepare for the job, and extensive training programme), and performance appraisal practices (reliable evaluation process, objective performance evaluation, aware of position available for promotion, head of the department aware of staff's career aspirations, and setting of performance objectives). These strategies of HRM practices appear to provide more reliable and potent strategy in influencing the intention to stay of non-academic staff.

Finally, like other studies, several limitations of the study have been identified. First, the scope of the HRM practices investigated in this study was limited. HRM practices utilised in this study focused only on training and development, compensation and benefits, performance appraisal, and recruitment and selection. More research is needed to better distinguish between the general HRM practices that can suit the general groups of employees as a whole and the special HRM practices designed for a specific group of employees, thought to have specific needs.

Second, since this study used the quantitative method, future research may focus on using mixed methods to add to the usefulness of the conclusion of this study. This can provide further understanding and insights on the acceptable sets of HRM practice-level categories, generational diversity effects and their influences towards their intention to stay.

\section{References}

Ahmad, H., \& Ibrahim, B. (2015). Leadership and the characteristic of different generational cohort towards job satisfaction. Procedia - Social and Behavioral Sciences, 204, 14-18.

Aminuddin, M. (2014). Human resource management principles and practices. Shah Alam: Oxford University Press.

Delery, J. E., \& Doty, D. H. (1996). Modes of theorizing in strategic human resource management: Tests of universalistic, contingency, and configurationally performance predictions. Academy of Management Journal, 39(4), 802-835.

Department of Statistics Malaysia. (2019). Key statistics of labour force in Malaysia, July 2019. Retrieved from https://www.dosm.gov.my/v1/index.php?r=column/pdfPrev\&id=eWtsKy9TL3NnSjdl N1JUdkNZYndUUT09.

Gursoy, D., Chi, C. G. Q., \& Karadag, E. (2013). Generational differences in work values and attitudes among frontline and service contact employees. International Journal of Hospitality Management, 32, 40-48. doi:10.1016/j.ijhm.2012.04.002

Harun, S., Shahid, S. A. M., \& Othman, A. K. (2016). The Influence of HRM Practices Towards PHEls Non-Academic Staff Intention to Stay: A Conceptual Model. J. Appl. Environ. Biol. Sci, 6(5S), 82-89.

Harun, S., Shahid, S. A. M., \& Othman, A. K. (2017). Promoting Employees' Loyalty: Incorporating the Turnover Models Approach. Advanced Science Letters, 23(8), 73557358. 
Hendricks, J. M., \& Cope, V. C. (2013). Generational diversity: What nurse managers need to know. Journal of Advanced Nursing, 69(3), 717-725.

Howe, N., \& Strauss, W. (1991). Generations: The history of America's future, 1584 to 2069. New York: William Morrow \& Company, 538.

Khatri, N. (2000). Managing human resource for competitive advantage: A study of companies in Singapore. The International Journal of Human Resource Management, 11(2), 336365. doi:10.1080/095851900339909

Mannheim, K. (1952). Historicism. Essays on the Sociology of Knowledge. New York: Harcourt, Brace \& World.

Meijerink, J. G., Bondarouk, T., \& Lepak, D. P. (2016). Employees as active consumers of HRM: Linking employees' HRM competences with their perceptions of HRM service value. Human Resource Management, 55(2), 219-240.

Mowday, R. T., Koberg, C. S., \& McArthur, A. W. (1984). The psychology of the withdrawal process: A cross-validation test of Mobley's intermediate linkages model of turnover in two samples. Academy of Management Journal, 27(1), 79-94.

Nitya, R., \& Anand, S. (2016). A study on generational differences in work values and personorganization fit and its effect on turnover intention of Generation $Y$ in India. Management Research Review, 39(12), 1695-1719. doi:10.1108/MRR-10-2015-0249

Parry, E., \& Urwin, P. (2011). Generational differences in work values: A review of theory and evidence. International journal of management reviews, 13(1), 79-96.

Pinto, A. M. G. L. R. S., da Silva Ramos, S. C. M., \& Nunes, S. M. M. D. (2014). Managing an aging workforce: What is the value of human resource management practices for different age groups of workers? Tékhne, 12, 58-68.

Shahid, S. A. M., Rahman, M. K. B. A., Harun, S., Othman, A. K., \& Naina, R. (2018). Assessing the influence of HRM practices in improving employees intention to stay in one Malaysian medical college: A pilot study. International Journal of Multidisciplinary Thought, 07(03), 449-462.

Stone, D. L., \& Deadrick, D. L. (2015). Challenges and opportunities affecting the future of human resource management. Human Resource Management Review, 25(2), 139145.

Walsh, J. P., Ashford, S. J., \& Hill, T. E. (1985). Feedback obstruction: The influence of the information environment on employee turnover intentions. Human Relations, 38(1), 23-46.

Zikmund, W. G., Babin, B. J., Carr, J. C., \& Griffin, M. (2013). Business research methods (9th ed.). Singapore: Cengage Learning Asia Pte Ltd. 